\title{
Effects of attractants inclusion on the growth and survival of Channa striata
}

\author{
JOYSHRI SARKER, S.M. RASHADUL ISLAM, MOHAMMAD REDWANUR \\ RAHMAN, TASHRIF MAHMUD MINHAZ AND HELENA KHATOON ${ }^{1^{*}}$ \\ Department of Aquaculture, Chattogram Veterinary and Animal Sciences University \\ Chattogram 4225, Bangladesh \\ Corresponding Author: helena@cvasu.ac.bd
}

\begin{abstract}
An experiment was conducted to evaluate the efficacy of different natural and artificial attractants in the diet of stripped snakeheads Channa striata. The experiment was conducted into two phases- Nursery and Grow-out. There were four treatments TC (Control), TG (Glycine), TA (Alanine) and TN (Nappi) for each phase with three replicates. In phase-1, the fry/fingerling were fed three times daily for four months; in phase-2, the fish were fed twice daily in the morning and afternoon for six months where the effects of formulated diets were compared with control (TC) which is locally available as commercial feed. In phase-1, significantly $(p<0.05)$ lower FCR $(1.58 \pm 0.13)$, higher individual weight gain $(91.90 \mathrm{~g})$, higher SGR $(2.47 \pm 1.79 \% /$ day $)$, higher survival $(90 \%)$, and higher feeding efficiency $(57.60 \pm 5.54 \%)$ were found in the control (TC) compared to all other treatments. On the other hand, in phase-2, significantly $(p<0.05)$ lower FCR $(1.63 \pm 0.06)$, higher individual weight gain $(299 \mathrm{~g})$, and higher feeding efficiency $(45.96 \pm 1.63 \%)$ were found in Nappi (TN) supplemented diet whereas significantly $(p<0.05)$ higher survival $(93.33 \%)$ and higher SGR $(0.90 \pm 0.17 \% /$ day) were found in Glycine (TG) supplement diet compared to the control (TC). Therefore, domestication and then the addition of natural and artificial attractants in formulated feeds may enhance the efficacy of formulated feeds for better growth and survival of the carnivorous fish like stripped snakeheads especially in grow-out phase. Hence, this finding will help to culture $C$. striata using protein-rich formulated feed adding attractants rather than depending on any live feed or formulated feed which is not commercially feasible.
\end{abstract}

Keywords: Channa striata, Carnivore, Attractant, Formulated feed, FCR

\section{Introduction}

Cultured snakehead has become an economically important freshwater fish in developing countries as Thailand, Malaysia, Indonesia, Bangladesh, India and Vietnam. In 2016, the total global capture and aquaculture production of snakehead Channa striata reached 92,523 MT (FAO 2019). C. striata, along with other species of the genus Channa, contributes $2.03 \%$ of the total fish production in Bangladesh (FRSS 2018). As food fish, C. striata has a great market demand in Bangladesh and rich in nutritional value also. Many snakeheads are commonly used in aquaculture and are highly valued as food fish in different countries (Courtenay and Williams 2004). Due to the destruction of the feeding, breeding and nursery ground its production is decreasing day by day in Bangladesh. Unfortunately, there is no commercially available feed formulated for this species specifically and only little empirical information on its nutritional requirements has been reported so far (Shan et al. 2016). Live food is a requirement for snakehead culture in larval stage and sometimes in grow-out stage also. However, this problem has now been overcome to some extent by the development of good quality artificial diet. Although culture of $C$. striata requires live fish fry, formulated feed containing $36 \%$ protein could be used for better growth and feed utilization efficiencies of snakehead C. striata juveniles (Mithu et al. 2017). But for the economic success of snakehead

https://doi.org/10.52168/bjf.2021.33.05 
culture there is a need to maximize the feed acceptability, feed consumption and reduce the feed wastage. This can be achieved by use of feed attractants in culture practices. Feed attractants are chemicals which make animal to orient towards the source of these chemicals. Food attractiveness and stimulation of fish ingestion involve physical stimuli, such as color and movement, as well as chemical stimuli, such as 'smell' and taste of food particles (Kolkovski et al. 1997). Attractants are mainly used to enhance feed intake, growth and nutrient utilization in farmed aquatic animals. The feed attractants are specific compounds or ingredients added to the feed to enhance the diet palatability and consequently, its acceptability by fish (Smith et al. 2005). Further, protein and energy metabolism can be enhanced by nutrients that are contributed by attractants (Papatryphon and Soares 2001). Tiril et al. (2008) reported that the higher feed intake and thus growth rate in a considerable manner when betaine was added to diet for rainbow trout. But there is lack of studies on the effects of feed attractants in snakehead culture. Therefore, the present study was carried out to know the efficacy of natural and chemo attractant on $C$. striata to boost the farming of this promising species.

\section{Materials and Methods}

Experimental fish: Fry of Vietnamese Channa striata were collected from a fish farm named Al-Amin fish farm and hatchery of Mymensingh, Bangladesh and conditioning was done for one week before starting the experiment.

Experimental Design: This experiment was performed in two phases (Nursery and Grow-out) and in each phase there were four different treatments with three replications. Phase-1 was considered as nursery stage where chemo attractant such as Glycine (TG) and Alanine (TA) was used along with a locally available natural attractant Nappi (TN) to increase the acceptance of formulated feed. To compare the performance of those feeds with the commercial nursery feed, a commercial feed named Agata feed was also used as control (TC). The initial average weight of the stocked fish was $3.70 \mathrm{~g}$. The stocking density was maintained same for four treatments $\left(30 / \mathrm{m}^{3}\right)$. The fish were fed three time a day.

In phase- 2 , we used the same treatments like the phase- 1 except the Control (TC). The control feed was formulated following the same ration of the other experimental feeds but without attractants. The initial average weight of the stocked fish in grow-out stage was $51.00 \mathrm{~g}$. The fishes were collected from the reared fish in the Phase 1. Here the stocking density was same like the phase- 1 but this time the water depth and aeration was increased. Water exchange was amounted to $70-80 \%$ of the total unit volume with freshwater in every alternate day. The fish were fed twice a day and growth performance was checked twice in a month.

Feed formulation: The formulation of experimental feed with attractants for phase-1 and phase2 is shown in Table I. Glycine, Alanine, and Nappi were used as attractant with formulated diets and designated as TG, TA, and TN diet respectively. The ingredients were mixed (except vitamin-mineral premix and attractants) thoroughly, made into dough with water and then vitamin-mineral mix and attractants was thoroughly mixed with the dough and pellet was prepared through a hand pellet machine. The pellet feeds were dried and stored until use. As carnivorous in nature, C. striata requires high protein feed. For this reason, on the basis of 
protein requirement two different feed were formulated where $35 \%$ and above $40 \%$ protein was maintained for the fish of phase- 2 and phase- 1 respectively.

Table I. Ration for phase 1 (nursery stage) and phase 2 (grow out stage) experiment

\begin{tabular}{|c|c|c|c|c|c|c|c|}
\hline \multirow{3}{*}{ Ingrediants } & & & \multicolumn{5}{|c|}{ Protein Percentage } \\
\hline & \multicolumn{2}{|c|}{ Quantity } & \multirow{2}{*}{$\begin{array}{l}\text { Protein } \\
\text { percent }\end{array}$} & \multicolumn{2}{|c|}{ Diet Formulation } & \multicolumn{2}{|c|}{ Protein in diet } \\
\hline & Phase-1 & Phase-2 & & Phase-1 & Phase-2 & Phase-1 & Phase-2 \\
\hline Fish meal & $750 \mathrm{~g}$ & $475 \mathrm{~g}$ & $50 \%$ & $71.0 \%$ & $45.0 \%$ & $37.5 \%$ & $23.75 \%$ \\
\hline Soyabean meal & $100 \mathrm{~g}$ & $175 \mathrm{~g}$ & $42 \%$ & $9.5 \%$ & $16.4 \%$ & $4.2 \%$ & $7.35 \%$ \\
\hline Rice bran & $100 \mathrm{~g}$ & $175 \mathrm{~g}$ & $12 \%$ & $9.5 \%$ & $16.4 \%$ & $1.2 \%$ & $2.10 \%$ \\
\hline Maize bran & $50 \mathrm{~g}$ & $175 \mathrm{~g}$ & $10 \%$ & $5.0 \%$ & $16.4 \%$ & $0.5 \%$ & $1.75 \%$ \\
\hline $\begin{array}{l}\text { Vitamin-mineral } \\
\text { premix }\end{array}$ & $10 \mathrm{~g}$ & $10 \mathrm{~g}$ & --- & $1.0 \%$ & $1.0 \%$ & $\begin{array}{c}-- \\
\end{array}$ & --- \\
\hline $\begin{array}{l}\text { Di-calcium } \\
\text { phosphate }\end{array}$ & $20 \mathrm{~g}$ & $20 \mathrm{~g}$ & --- & $2.0 \%$ & $2.0 \%$ & --- & --- \\
\hline Binders & $10 \mathrm{~g}$ & $10 \mathrm{~g}$ & --- & $1.0 \%$ & $1.0 \%$ & --- & --- \\
\hline Fenugreek & $10 \mathrm{~g}$ & $10 \mathrm{~g}$ & --- & $1.0 \%$ & $1.0 \%$ & --- & --- \\
\hline Molasses & $10 \mathrm{ml}$ & $10 \mathrm{ml}$ & --- & --- & --- & --- & --- \\
\hline Fish oil & $5 \mathrm{ml}$ & $5 \mathrm{ml}$ & --- & --- & --- & --- & --- \\
\hline \multirow{2}{*}{$\begin{array}{l}\text { Attractants } \\
\text { (Artificial/ } \\
\text { natural) }\end{array}$} & $(5 / 50) \mathrm{g}$ & $(5 / 50) \mathrm{g}$ & --- & $1 / 5 \%$ & $1 / 5 \%$ & --- & --- \\
\hline & & & & $100 \%$ & $100 \%$ & $43.4 \%$ & $34.95 \%$ \\
\hline
\end{tabular}

Assessing growth performance and feeding efficiency: To assess the effects of dietary chemo attractants on growth and condition, all fry in the tank were counted and weighted to record data. For monitoring the growth performance of the fry and efficacy of the feeds final growth gained by $(\mathrm{cm})$, weight gain $(\mathrm{g})$, percent weight gain, FCR, and survival rate (\%) were calculated based on the following formulae:

Mean weight gain $(\mathrm{g})=(\mathrm{W} 2-\mathrm{W} 1)$

Specific growth rate $(\mathrm{SGR}) \%=\frac{\ln W 2-\ln W_{1}}{\text { Experimental period }} \times 100$

Mean Weight gain $(\%)=\frac{\text { wh-W }}{\text { Mays nf experimant }} \times 100$

Total biomass/Yield $(\mathrm{g})=$ Final number of fish $\times$ Mean final weight

$\mathrm{FCR}=\frac{\text { The amount of given feed }}{\text { W2-W1 }} \times 100$

Feeding Efficiency $=\frac{\text { W.W1 }}{\text { Amovent of fosd intalse during the culturs poriad }} \times 100$

Where,

$\mathrm{W}_{1}=$ Weight at the start of the experiment; $\mathrm{W}_{2}=$ Weight at the end of the experiment 
Survival rate: Survival percentage was calculated at the end of the experiment by counting the number of fish in tank and is calculated as follows:

Survival $(\%)=\frac{\text { Number of surviving fi sh }}{\text { Total number of larvae stocked }} \times 100$

Analysis of proximate composition: In this experiment proximate composition such as protein, lipid, carbohydrate, moisture and ash of the formulated feeds were carried out according to the standard methods. Micro Kjeldhal method (Kirk and Sawyer 1991) was used to determine the crude protein content. Crude lipid was determined using the procedure of AOAC (2005) using hexane $\left(65^{\circ} \mathrm{C}-70^{\circ} \mathrm{C}\right)$ as the solvent. Analysis of carbohydrate was done by using the method of Dubois et al. (1956). Two grams of sundried samples were taken in an ash-free filter paper (predried at $100^{\circ} \mathrm{C}$ to constant weight) placed in a glass Petri plate. The samples were then dried again in an oven at $100^{\circ} \mathrm{C}$ for $6-12 \mathrm{~h}$ or until constant weight was observed. The moisture content was calculated using the formula below (Horwitz 1984):

$\%$ Moisture $=1 / 4($ wt. of oven dried samples/wt. of original samples $) \times 100$

$\%$ Dry matter $=1 / 4100-\%$ moisture

To estimate the ash content, the crucible containing dried sample obtained from the moisture determination exercise was placed in a muffle furnace and heated at $550^{\circ} \mathrm{C}$ to $600^{\circ} \mathrm{C}$ for $6 \mathrm{~h}$ and till the sample reduced to ash. The ash content was calculated as:

$\%$ Ash $=1 / 4$ (Weight of ash $/$ Weight of dried samples $) \times 100$. The proximate composition of the experimental diets of phase- 1 and phase- 2 is presented in Table II.

Table II. Proximate composition of formulated feed fed to $C$. striata in phase-1 and phase-2

\begin{tabular}{c|c|c|c|c|c|c|c}
\multicolumn{2}{l|}{ Feed type } & $\begin{array}{c}\text { Moisture } \\
(\%)\end{array}$ & $\begin{array}{c}\text { Lipid } \\
(\%)\end{array}$ & $\begin{array}{c}\text { Crude Protein } \\
(\%)\end{array}$ & $\begin{array}{c}\text { Fiber } \\
(\%)\end{array}$ & $\begin{array}{c}\text { Ash } \\
(\%)\end{array}$ & $\begin{array}{c}\text { Carbohydrate } \\
(\%)\end{array}$ \\
\hline \multirow{2}{*}{ TC } & $*$ Phase-1 & 6.00 & 5.20 & 40.00 & 7.60 & 7.76 & 33.44 \\
\cline { 2 - 8 } & $* *$ Phase-2 & 25.00 & 6.50 & 34.95 & 8.90 & 8.00 & 16.65 \\
\hline \multirow{2}{*}{ TG } & Phase-1 & 25.00 & 6.90 & 43.40 & 9.70 & 8.10 & 6.90 \\
\cline { 2 - 8 } & Phase-2 & 25.00 & 6.50 & 34.95 & 8.90 & 8.00 & 16.65 \\
\hline \multirow{2}{*}{ TA } & Phase-1 & 25.00 & 6.90 & 43.40 & 9.70 & 8.10 & 6.90 \\
\cline { 2 - 8 } & Phase-2 & 25.00 & 6.50 & 34.95 & 8.90 & 8.00 & 16.65 \\
\hline \multirow{2}{*}{ TN } & Phase-1 & 25.00 & 6.90 & 43.40 & 9.70 & 8.10 & 6.90 \\
\cline { 2 - 8 } & Phase-2 & 25.00 & 6.50 & 34.95 & 8.90 & 8.00 & 16.65 \\
\hline
\end{tabular}

*In phase-1 commercial feed (Agata feed) was used as control. **In phase 2 formulated feed (without attractants) used as control. Dry weight basis.

Water quality parameter: Temperature, dissolved oxygen and $\mathrm{pH}$ in the culture tanks were measured daily using a YSI 556 MPS (YSI, New Jersey, USA).

Data collection and analysis: Initially, fish were stocked after taking initial weight $(\mathrm{g})$ and from then every 15 days interval field data such as weight gain and mortality were collected and recorded for further analysis. All statistical analyses were performed in SPSS 21.0 for Windows (SPSS Inc.) using one-way analysis of variance (ANOVA). Significant differences amongst treatments were determined using Duncan's multiple range tests at 0.05 levels. 
JOYSHRI SARKER et al.

\section{Results}

Biological parameter: Phase-1: Significantly $(p<0.05)$ higher weight gain $(91.90 \mathrm{~g})$ and SGR $(2.47 \pm 1.79 \%$ day-1) was found in TC compared to other treatments and lower weight gain $(57.00 \mathrm{~g})$ and SGR $(2.16 \pm 1.05 \%$ day-1) was recorded in TA (Fig. 1A and 2A). Significantly $(p<0.05)$ higher survival rate $(90 \%)$ was recorded in TC and lower survival rate $(80 \%)$ was recorded in TN (Fig. 3A). Significantly $(p<0.05)$ lower FCR $(1.58 \pm 0.13)$ was found in TC and higher FCR $(1.90 \pm 0.24)$ was found in TA (Table III). The feeding efficiency of fish were significantly different $(p<0.05)$ in all the treatments and control with the highest rate in TC $(57.60 \pm 5.54 \%)$ and

lowest in TA $(39.98 \pm 4.61 \%)$ (Table III). Fish fed with commercial feed (TC) which is control treatment had significantly $(p<0.05)$ higher yield $(2111.40 \pm 30.32 \mathrm{~g})$ and fish fed with alanine included diet (TA) had lower yield $(1482.20 \pm 18.40 \mathrm{~g})$ compared to other treatments (Table III).

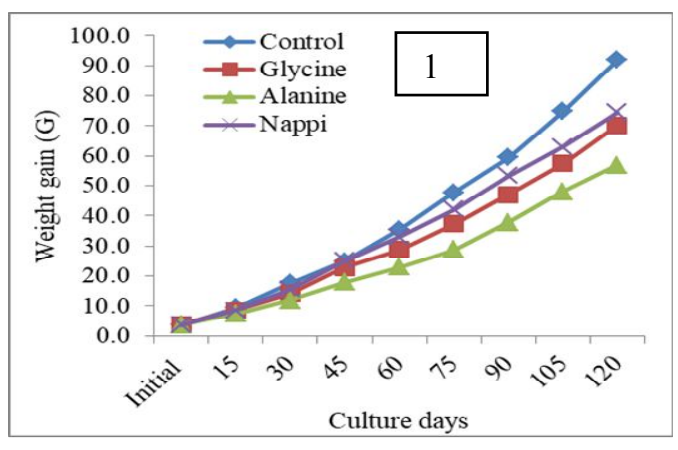

Nursery stage

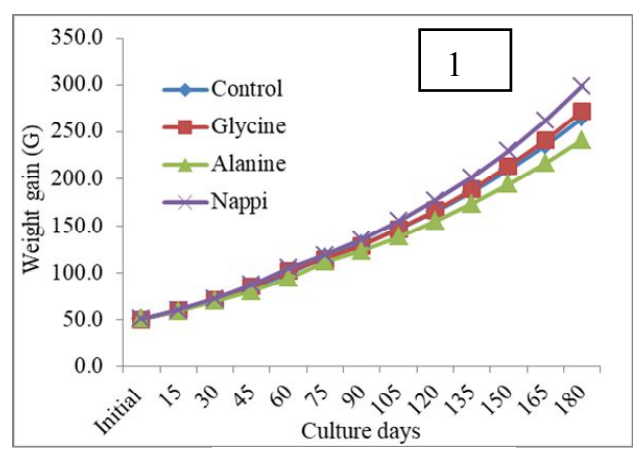

Grow-out stage

Fig. 1. Mean average weight gain of $C$. striata in different treatments at $95 \%$ significance level.

Biological parameters Phase-2: Significantly $(p<0.05)$ higher weight gain $(299 \mathrm{~g})$ was found in TN compared to other treatments and lower weight gain $(241 \mathrm{~g})$ was recorded in TA (Fig. 1B). In case of specific growth rate TG showed significantly $(p<0.05)$ higher SGR $(0.90 \pm 0.17$ $\%$ day $\left.^{-1}\right)$ and lower SGR $\left(0.78 \pm 0.21 \%\right.$ day $\left.^{-1}\right)$ was observed in TA (Fig. 2B). Significantly $(p<0.05)$ higher survival rate $(93.33 \%)$ was recorded in TG and lower survival rate $(80 \%)$ was recorded in TN (Fig. 3B). There were no significant difference of survival rate between TC and TA (Fig. 2C). Significantly $(p<0.05)$ lower FCR $(1.63 \pm 0.06)$ was found in TN and higher FCR $(1.95 \pm 0.11)$ was found in TA (Table III). The feeding efficiency of fish were significantly different $(p<0.05)$ in all the treatments and control with the highest rate in TN $(45.96 \pm 1.63 \%)$ and lower rate in TA $(38.48 \pm 2.02 \%)$ (Table III). Fish fed with $\left.\mathrm{T}_{\mathrm{G}}\right)$ had significantly $(\mathrm{p}<0.05)$ higher yield (7613.20 $\pm 70.94 \mathrm{~g}$ ) and fish fed with alanine included diet (TA diet had lower yield $(6266.00 \pm 61.58 \mathrm{~g})$ compared to other treatments (Table III). 


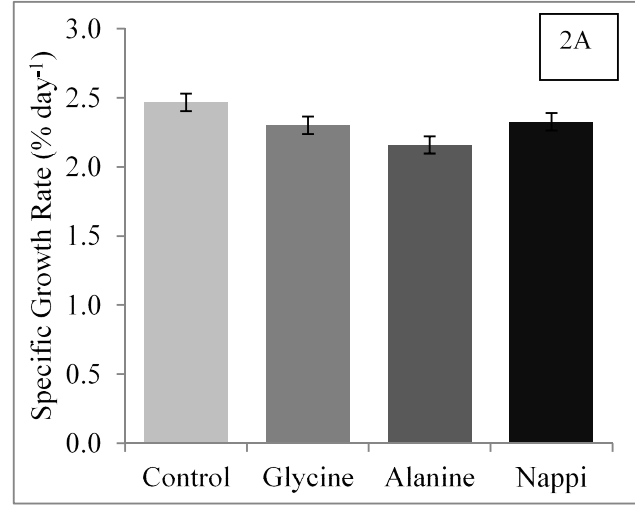

Nursery stage

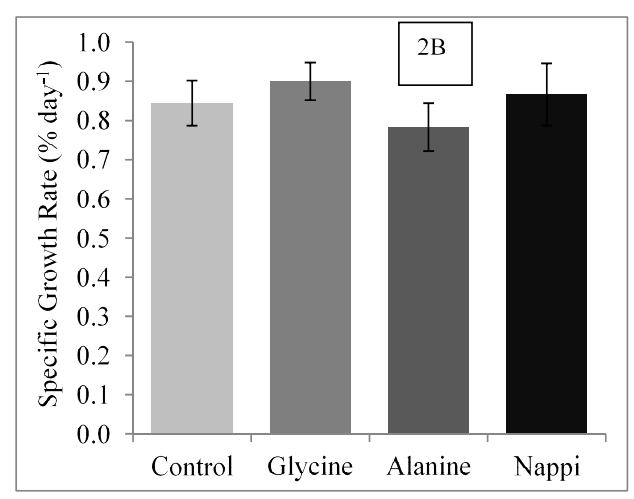

Grow-out stage

Fig. 2. Specific growth rate of $C$. striata in different treatments at $95 \%$ significance level.

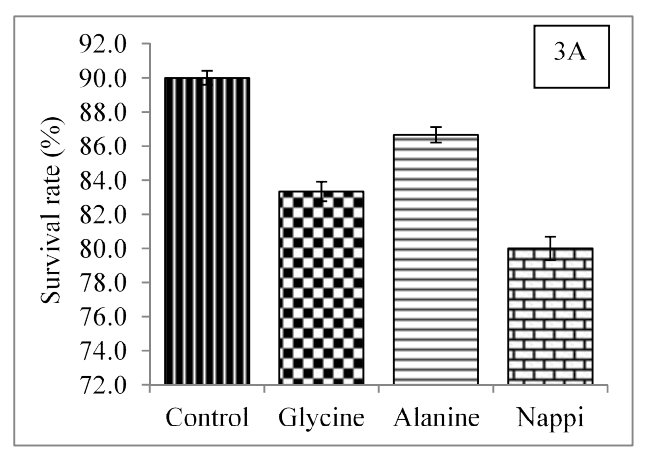

Nursery stage

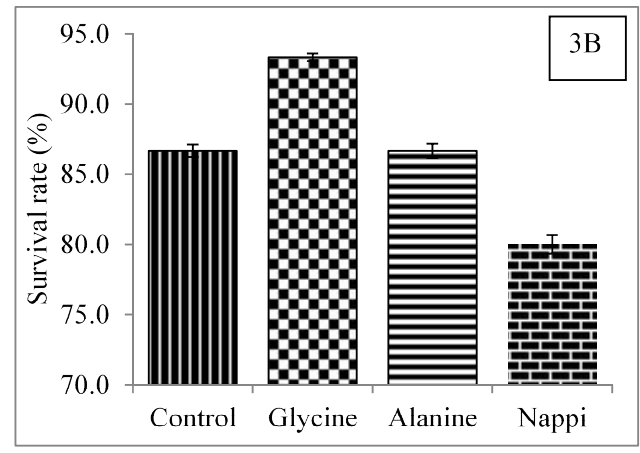

Grow-out stage

Fig. 3. Survival rate of $C$. striata in different treatments at $95 \%$ significance level. 
JOYSHRI SARKER et al.

Table III. Mean values \pm standard error of FCR, feeding efficiency and yield in different treatments

\begin{tabular}{l|c|c|c}
\hline Parameters & Treatment & Phase 1 & Phase 2 \\
\hline \multirow{3}{*}{ FCR } & TC & $1.58 \pm 0.13^{\mathrm{a}}$ & $1.82 \pm 0.05^{\mathrm{bc}}$ \\
& TG & $1.71 \pm 0.26^{\mathrm{b}}$ & $1.73 \pm 0.07^{\mathrm{b}}$ \\
& TA & $1.90 \pm 0.24^{\mathrm{c}}$ & $1.95 \pm 0.11^{\mathrm{c}}$ \\
& TN & $1.61 \pm 0.26^{\mathrm{a}}$ & $1.63 \pm 0.06^{\mathrm{a}}$ \\
\hline \multirow{3}{*}{ Feeding } & TC & $57.60 \pm 5.54^{\mathrm{a}}$ & $41.14 \pm 1.17^{\mathrm{b}}$ \\
efficiency $(\%)$ & TG & $44.95 \pm 7.41^{\mathrm{bc}}$ & $43.40 \pm 1.67^{\mathrm{ab}}$ \\
& TA & $39.98 \pm 4.61^{\mathrm{c}}$ & $38.48 \pm 2.02^{\mathrm{c}}$ \\
& TN & $47.91 \pm 8.31^{\mathrm{b}}$ & $45.96 \pm 1.63^{\mathrm{a}}$ \\
\hline \multirow{3}{*}{ Yield (g) } & TC & $2111.40 \pm 30.32^{\mathrm{a}}$ & $6890.00 \pm 69.06^{\mathrm{b}}$ \\
& TG & $1757.50 \pm 22.27^{\mathrm{b}}$ & $7613.20 \pm 70.94^{\mathrm{a}}$ \\
& TA & $1482.20 \pm 18.40^{\mathrm{c}}$ & $6266.00 \pm 61.58^{\mathrm{c}}$ \\
& TN & $1788.00 \pm 24.74^{\mathrm{b}}$ & $7176.00 \pm 79.33^{\mathrm{ab}}$ \\
\hline
\end{tabular}

*Means in the same column with the different letters are significantly different $(p>0.05)$

Water quality parameters: Dissolved oxygen, $\mathrm{pH}$ and temperature of the both phases were in recommended range for snakehead culture. There were no significant differences $(p>0.05)$ found in water with regards to dissolved oxygen, temperature $\left({ }^{\circ} \mathrm{C}\right)$ and $\mathrm{pH}$ between the treatments and the control tanks (Table IV).

Table IV. Mean values \pm standard error of dissolved oxygen, temperature and $\mathrm{pH}$ range in control and treated tanks during the experimental period

\begin{tabular}{c|cc|cc|cc}
\hline \multirow{2}{*}{ Treatment } & \multicolumn{6}{|c}{ Parameter } \\
\cline { 2 - 7 } & \multicolumn{2}{|c|}{ DO $(\mathrm{mg} / \mathrm{L})$} & \multicolumn{2}{c}{$\mathrm{pH}$} & \multicolumn{2}{c}{ Temperature $\left({ }^{\circ} \mathrm{C}\right)$} \\
\cline { 2 - 7 } & Phase 1 & Phase 2 & Phase 1 & Phase 2 & Phase 1 & Phase 2 \\
\hline TC & $5.5 \pm 0.02$ & $5.0 \pm 0.01$ & $7.4-7.8$ & $7.1-7.9$ & $28.5 \pm 0.01$ & $29.3 \pm 0.01$ \\
TG & $5.5 \pm 0.01$ & $5.0 \pm 0.02$ & $7.3-7.7$ & $7.4-7.8$ & $28.5 \pm 0.01$ & $29.3 \pm 0.03$ \\
TA & $5.5 \pm 0.02$ & $5.0 \pm 0.02$ & $7.5-7.8$ & $7.3-7.8$ & $28.5 \pm 0.04^{\mathrm{a}}$ & $29.3 \pm 0.01$ \\
TN & $5.5 \pm 0.01$ & $5.0 \pm 0.01$ & $7.6-7.8$ & $7.5-7.8$ & $28.5 \pm 0.03^{\mathrm{a}}$ & $29.3 \pm 0.02$ \\
\hline
\end{tabular}

\section{Discussion}

Chemoreception is an important factor in feeding behavior of fish. Food search and recognition, tasting and feeding are influenced by chemical stimuli. Uses of feed attractants are very popular among aquaculture practitioners now a days. Different natural and artificial attractants can be used to enhance the acceptability of feed in aquaculture. In Phase-1 (Nursery stage) of this study, it was observed that glycine, alanine and nappi supplementation as feed attractants had not that much attractive role on feeding behavior of $C$. striata. On the contrary, the attraction of the fishes towards non-treated commercial feed was found better. Significantly higher individual weight gain, SGR and survival rate was found in commercial feed (control) group. The feeding efficiency was also higher and lower FCR was observed in case of commercial feed compared to all attractants supplemented feed. This situation might be due to introduction of commercial feed during the weaning period of $C$. striata before their collection. As the fishes were adapted to the formulated feed before collection it was very certain that commercial feed showed better result than the other diets supplemented with attractants. Similar 
results were found in the tilapia fry (Paul et al. 2018) and in Thai pangas Pangasius hypophthalmus fed with different commercial feeds as they were adapted to the commercial feeds (Kader et al. 2003). Among the attractants supplemented treatments, nappi was found to increase growth and better feed utilization. Alanine supplemented feed had better survival rate than the other two.

In phase-2 (Grow-out stage) of the present study, feed attractants had a positive effect on the growth and survival of $C$. striata over the control group. Nappi was found to increase individual weight gain significantly and feeding efficiency among all the treatments and lower FCR was also observed in case of nappi and glycine supplemented feed. The growth performances of attractant included feeds were higher than the control in this study. The feeding efficiency of glycine added feed was also higher than the control. Similar observations were made by other experiments using attractants in fish feed. Stimulant supplementation can affect not only feed intake and subsequently weight gain but also food conversion ratio indicating an overall increase in diet efficiency (Papartyphon and Soares 2001). The weight gain, protein efficiency ratio, temperature growth coefficient and daily growth coefficient were found higher in attractant supplemented feed than the control in Labeo rohita (Paul et al. 2004). Growth, food conversion ratio, protein retention efficiency and energy retention efficiency was improved in rainbow trout fed plant protein diets containing the feeding stimulant taurine (Gaylord et al. 2006). Hybrid snakehead fed the shrimp paste diet had the higher growth performance than the control treatment which can be speculated that shrimp paste acted as the feed attractants (Fang et al. 2019). Another study in freshwater prawn (Macrobrachium rosenbergii) the weight gain, feed intake and food conversion ratio (FCR) were improved in prawn fed the three glycine-betaine added diet (Felix and Sudharsan 2004). In this study, feed prepared with glycine was found to significantly increase survival rate and SGR compared to other attractants and the control. Another study observed that growth performance of tilapia was improved by supplementation of $\mathrm{N}$-acetyl cysteine and glycine (Xie et al. 2016). But difference of survival rate among the treatments of both phases were very few which indicates that the dietary nappi, glycine and alanine supplementation affects little in case of survival rate. Similarly, addition of betaine had no effect on survival rate and highest survival rate was found in fingerlings fed feed without betaine (Zakipour et al. 2012). Attractant supplementation in diet also played role to increase the total yield where glycine containing feed had the highest yield and the yield of nappi added feed was also higher than the control in the current study. As the individual weight gain and SGR were increased and as a result yield was increased by using feed attractants. Fekrandish et al. (2005) also observed that, although attractants did not increase the nutritional value of formulated diet but they are useful to increase the food palatability and acceptance and increase the consumption of poor quality food. Kasumyan and Doving (2003) by using chemo-attractants overcame some problems such as rejection by fish and increasing the consumption of poor quality food. Therefore, overall it is observed that both natural and artificial feed attractants can enhance growth, survival rate, yield and acceptability of feed. However, there are variations in results of different studies whether growth or survival rate or yield or feed acceptability is increased, because of different culture condition and different fish species. The present study indicates that, both natural and artificial feed attractants have a great impact on growth and survival of $C$. striata. 
The result from present study indicated that dietary nappi and glycine significantly improved growth, survival rate and feed utilization of $C$. striata in the grow-out stage. Although commercial feed performed better in nursery stage due to their adaptability to commercial feed before their collection, the formulated feed supplemented with attractants showed an overall better performance on the growth and survival of $C$. striata in the grow-out stage. So, a farmer can easily be benefited culturing snakeheads by using formulated feed with attractants. Further study should be carried out to know the efficacy of other attractants in feed in different fish species culture.

Acknowledgements: We are grateful to the University Grants Commission (UGC), Bangladesh (Memo-cvasu/sta/2008/1008-6, UGC budget code-5921) for providing the fund through CVASU in this research. We are grateful to the Director of Institute of Coastal Biodiversity, Marine Fisheries and Wildlife Conservation to let us conduct this research experiment. We acknowledge the staffs and MS students of the CVASU who were involved in this project.

\section{Literature Cited}

AOAC, 2005. Official method of analysis. 18th Edition, Association of officiating analytical chemists, Washington DC, Method 935.14 and 992.24.

Courtenay, W.R. and J.D. Williams, 2004. Snakeheads (Pisces, Channidae) - A biological synopsis and risk assessment. US Geological Survey, Gainesville.

DuBois, M., K.A. Gilles, J.K. Hamilton, P.A. Rebers, and F. Smith, 1956. Colorimetric method for determination of sugars and related substances. Anal. Chem., 28(3): 350-356.

Fang, H., J. Xie, S. Liao, T. Guo, S. Xie, Y. Liu, L. Tian and J. Niu, 2019. Effects of dietary inclusion of shrimp paste on growth performance, digestive enzymes activities, antioxidant and immunological status and intestinal morphology of hybrid snakehead (Channa maculata $\% \times$ Channa argus $\sigma^{\prime}$ ). Front. Physiol., 10: 1027.

FAO, 2019. Fisheries and aquaculture department. Species fact sheet. Channa striata (Bloch, 1973).

Fekrandish, H., A.M. Abedian, A. Matinfar and A. Dehqhani, 2005. Influence of betaine and methionine in the diet for stimulating food intake of Indian white shrimp (Fenneropenaeus indicus). Pajouhesh Sazandegi., 73: 136-147.

Felix, N. and M. Sudharsan, 2004. Effect of glycine-betaine, a feed attractant affecting growth and feed conversion of juvenile freshwater prawn Macrobrachium rosenbergii. Aquac. Nutr., 10(3): 193-197.

FRSS (Fishery Resources Survey System), 2008. Fishery statistical yearbook of Bangladesh. Department of Fisheries, Dhaka. 47p.

Gaylord, T.G., A.M. Teague, and F.T. Barrows, 2006. Taurine supplementation of all-plant protein diets for rainbow trout (Oncorhynchus mykiss). J. World Aquac. Soc., 37(4): 509-517.

Horwitz, J.L., 1984. Features of ion trajectories in the polar magnetosphere. Geophys. Res. Lett., 11(11): 1111-1114.

IUCN, 1998. List of threatened animals of Bangladesh. Proceedings of the workshop on Bangladesh red book of threatened animals. Dhaka, Bangladesh. 13p.

Kader, M.A., M.A. Hossain and M.D. Hossain, 2003. A comparative study on the effect of commercial fish feeds on the growth of Thai pangas, Pangasius hypophthalmus. Bangladesh J. Fish. Res., 7(1): 53-58.

Kasumyan, A.O., and K.B. Doving, 2003. Taste preferences in fishes. Fish Fish., 4: 289-347.

Kirk, R.S. and R. Sawyer, 1991. Pearson's composition and analysis of foods, 9th ed. (student edition), England: Addision Wesley Longman Ltd. 33-36pp.

Kolkovski, S., A. Arieli and A. Tandler, 1997. Visual and chemical cues stimulate micro diet ingestion in sea bream larvae. Aquac. Int., 5: 527-537. 
Mithu, M.M., M.G. Rabbane, M.A. Khaleque and M.G. Mustafa, 2017. Effect of formulated diets on growth performance and feed utilization efficiencies of snakehead Channa striatus juveniles. Int. J. Fish. Aquat. Stud., 5(3): 451-455.

Papartyphon, E. and J.H. Soares, 2000. The effect of dietary feeding stimulants on growth performance of striped bass, Morone saxatilis. Aquaculture, 185(3-4): 329-338.

Papatryphon, E and J.H. Soares, 2001. Optimizing the levels of feeding stimulants for use in high fish meal and plant feeding based diets for striped bass, Morone saxatilis. Aquaculture, 202(3): 279-288.

Paul, B.N., S. Sarkar, P.K. Mukhopadhyay and S.N. Mohanty, 2004. Effect of dietary attractant on feed utilization and growth of rohu Labeo rohita (Ham.) fry. Anim. Nutr. Feed Technol., 4(2): 145-152.

Paul, A.K., M.M. Rahman, M.M. Rahman and M.S. Islam, 2018. Effects of commercial feeds on the growth and carcass compositions of monosex tilapia (Oreochromis niloticus). J. Fish. Aquat. Sci., 13: $1-11$.

Smith, D.M., S.J. Tabrett, M.C. Barclay and S.J. Irvin, 2005. The efficacy of ingredients included in shrimp feeds to stimulate intake. Aquac. Nutr., 11(4): 263-272.

Shan, L., Z. Qui and H. Ye, 2016. A comparative analysis of the results of feeding the northern snakehead with three different diets. Sci. Fish Farm. 7: 70-71.

Tiril, S.U., F. Alagil, F.B. Yagci and O. Aral, 2008. Effects of betaine supplementation in plant protein based diets on feed intake and growth performance in rainbow trout (Oncorhynchus mykiss). Isr. J. Aquacult.-Bamid., 60(1): 57-64.

Xie, S., W. Zhou, L. Tian, J. Niu and Y. Liu, 2016. Effect of N-acetyl cysteine and glycine supplementation on growth performance, glutathione synthesis, anti-oxidative and immune ability of Nile tilapia, Oreochromis niloticus. Fish Shellfish Immun., 55: 233-241.

Zakipour, R.E., M. Akbari, A. Arshadi and E. Effatpanah, 2012. Effect of different levels of dietary betaine on growth performance, food efficiency and survival rate of pike perch (Sander lucioperca) fingerlings. Iran. J. Fish. Sci., 4: 902-910.

(Manuscript received: 29 June 2021) 